\title{
A Survey of Malaysian Experience in TQM
}

\author{
SALLEH YAHYA \\ LAILAWATI MOHD. SALLEH \\ GOH WEE KEAT \\ Faculty of Economics and Management \\ Universiti Putra Malaysia
}

\begin{abstract}
This study documents the experience of Malaysian firms in the implementation of TQM. Issues being explored and documented are years required to fully implement $T Q M$, benefits of $T Q M$, the different kinds of TQM training conducted, and reasons for not adopting TQM. This paper also shows that adoption of $T Q M$ leads to improvement in organizational performance, and that the involvement of employees and - senior executives is important to support TQMexecution, irrespective of a firm's paid-up capital and years of operation.
\end{abstract}

Key words: TQM, factors, benefits, performance, adoption.

\section{ABSTRAK}

Kajian ini adalah mengenai pengalaman firma Malaysia di dalam melaksanakan TQM. Isu-isu yang dikaji adalah tempoh yang diperlukan untuk melaksanakan sepenuhnya TQM, kebaikan TQM, perbezaan latihan TQM yang diperlukan dan sebab-sebab TQM tidak diamalkan oleh firma-firma. Kajian ini telah menunjukkan bahawa perlaksanaan TQM akan membawa kepada peningkatan prestasi organisasi dan - penglibatan pekerja serta eksekutif senior adalah penting di dalam keberkesanan perlaksanaan TQM, tanpa dipengaruhi oleh modal berbayar firma mahupun tahun operasi mereka.

\section{INTRODUCTION}

An organization's competitiveness by far hinges on its ability of continuous learning and improvement through its people, processes and technology. There are several alternatives and approaches that an organization can consider to enhance its learning and improvement ability. One of these approaches is TotalQuality Management. TotalQuality Management (TQM) is a philosophy as well as a set of guiding principles representing the foundations of an excellent organization (Besterfield et al.,1999). TQM integrates fundamental man- 
thip, reward and recognition, enror prevention, co-operation and teamwork (Hakes, 1991; Saylor, 1992; Hamzah and Ho, 1994). The implementation of TQM involves the deployment of the key elements or factors of these principles. The factors include both the "soft" factors of management such as employee involvement and empowerment, management commitment and leadership, cross-functional teamwork and organizational culture (Crosby, 1979; Deming, 1986; Wilkinson, 1992; Puffer and McCarthy, 1996; Thiagarajan et al., 2001), and also the "hard" factors such as quality systems, policies, quality tools and techniques (Oakland, 1993; Thiagarajan et al., 2001).

\section{LITERATURE REVIEW}

\section{Implementation of TQM}

Studies on foreign companies have shown that implementation of TQM tendstobring favorable outcomes. Several case studies registered positive outcomes of the TQM exercise, which includes reduced inventory level and steps in the manufacturing process (Peak, 1993), drop in rejection rate (Gupta and Sagar, 1993), development of new products and improvement in design (Eureka and Ryan, 1988; Gupta and Sagar, 1993), and changes in company culture (Chapman, et al., 1991). Positive signs of TQM implementation are also being detected when large-scale surveys have been carried out. Spe- cifically, studies by Ahire et al., (1996), Prabhu et al., (2000), Solis et al., (1998), Sun (1999), TerziovskiandSamson (1999), suggest thepresence of strong association between implementation of TQM with organizational performance. Ahire et al. (1996), although identified a similar pattern of association, have contended that it could be the execution of certain constructs or practices that lead to better performance, rather than adoption of TQM.

Such a positive relationship between adoption of TQM and improvement in organizational performance is largely the result of implementation of TQM critical success factors. These factors, if well attended, will act as the pillars of TQM, and generate the desired incremental improvement. In this respect, Saraph $e t$ al., (1989) could be considered as the pioneer in identifying and measuring these factors. Later, many different versions of critical factors have been proposed by researchers such as Mann (1992), and Thiagarajan and Zairi (1997a, 1997b, 1997c). With respect to a firm's size and TQM critical factors, Goh and Ridway (1994), and Mohd Yusof and Aspinwall (1999) attempted to formulate factors that are critical to small and medium enterprises, while Ahire et al. (1996) examined factors in the context of medium and larged size companies. Solis et al. (1998), on the other hand, emphasized on the type of company (i.e. services or manufacturing).

\section{Implementation of TQM in Malaysia}

In general, studies of implementation of TQM in Malaysia suggest that it is still in its infancy, with prevalence in large organizations, especially in the electrical and electronics sectors as compared to resource-based companies (Aziz and Chan, 1998; Idris et al., 1996; Zain and 
Ahmad, 2000). Various barriers such as management and employees' attitudes, lack of commitment, low level of quality knowledge, lack of resources, and fear of failure have been encountered during implementation of TQM (Aziz and Chan, 1998; Kanji et al., 1999).

Nonetheless, research by Agus and Abdullah (2000) has indicated of the positive association between the length of implementation of TQM with a company's financial performance. In addition, industrial manufacturing companies exhibit more intense implementation of TQM elements (executive com(1) mitment, customers' focus, suppliers' relations, - quality training, employees' focus, and quality measurement) than consumer manufacturing companies, with relatively stringent quality measures carried out in automotive and gas industries. With regard to the soft foundation of TQM's critical success factors, - Lau and Idris (2001) identified these elements (importance in descending order): culture, trust, teamwork, employment continuity, education and training, top management leadership for quality and continuous improvement, and customer satisfaction or involvement. All these soft factors have the following benefits, with varying degree, on TQM's tangible effects (growth, profitability, productivity, quality, finished product inspection, user demerit, market competitiveness, cost reduction, production, inventory, delivery date, safety, human resource development, development capability, marketing strength). Similarly, a survey by Idris et al. (1996) also indicated that the main benefits of TQM are customer satisfaction, teamwork, productivity, communication, and efficiency. Finally, Thiagarajan and Zairi's (1998) research using Malaysian companies as their sample offered a three tier of critical factors with different criticality.

\section{OBJECTIVE OF STUDY}

The TQM program has been implemented in many developed economies likes the USA, UK and Japan. A plethora of TQM research papers designated to these developed economies have been written and documented. However, study of implementation of TQM in a developing economies remains limited at best. The significance of knowledge of TQM in a developing nation context escalates when companies in this nation attempt to explore their alternatives in improving their company's performance in order to counter the opening of their home market to foreign competing companies. Compounded by the fact that it is uncertain of whether TQM is applicable across national borders, research of TQM in developing nations is certainly warranted. This paper positions itself as one of the many attempts in adding the richness of quality improvement literature in the context of developing nations, using Malaysia as the focus of the research. The questionnaire survey approach is used to achieve the research objectives.

The first objective of the paper is on the general aspects of implementation of TQM: time or duration required to fully implement the TQM concept in an organization, the training that is conducted to support the implementation of TQM, and the benefits of TQM. The TQM concept adopted by this paper is the same as that advocated by Besterfield et al. (1999); TQM is both a philosophy and a set of guiding principles representing the founda- 
tion of an excellent organization, integrating the fundamental management techniques, resources and its implementation altogether. Recognizing the fact that critical success factors applicablein developed economies may not entirely be suitable for developing nations, nine critical success factors have been listed for companies to indicate their perceived degree of importance in facilitating implementation of TQM. To extend the analysis further, this paper also attempts to analyze whether the criticality of the factors is dependent upon the size and years of operations of the firms. Two hypotheses are tested here:

$H_{0}$ (1): Quality factor criticality is the same for companies with different sizes.

$H_{0}$ (2): Quality factor criticality is the same for companies with different years of operation.

In addition to the above, it is also worth finding out why an organization chooses not to implement TQM. Thus, one open-ended question asking why the organization does not implement TQM is included in the questionnaire.

Table 1

Benefits of TQM

\begin{tabular}{llrr}
\hline & & $\mathbf{N}$ & (\%) \\
\hline Employee benefits & empowerment & 1 & 0.54 \\
& involvement/commitment/teamwork/communication & 19 & 10.33 \\
& skill \& knowledge & 6 & 3.26 \\
& employee better performance & 5 & 2.72 \\
& working environment & 4 & 2.17 \\
& quality awareness/culture & 13 & 7.07 \\
Firm benefits & reduced reject/defectrate & 6 & 3.26 \\
& increased sale/profit & 8 & 4.35 \\
& productivity & 15 & 8.15 \\
& improved quality & 18 & 9.78 \\
& control of quality/good quality management & 8 & 4.35 \\
& systematic management & 10 & 5.43 \\
& reduced wastage/cost & 17 & 9.24 \\
& effiencey/effectiveness/productivity & 14 & 7.61 \\
Customer benefits & 3 & 1.63 \\
Others & better understanding of customers & 22 & 11.96 \\
& & 15 & 8.15 \\
\hline
\end{tabular}

The second objective of the paper focuses on identifying the impact of TQM on the organization. In contrast to previous studies, on an organization. For the tangible effects or dimensions, Garvin's (1987) eight quality dimensions are used: features, performances, conformity, durability, reliability, repairable, style and design. For the intangible effects, and design. For the intangible effects, perceptual measures of organizational performance developed by Delaney and Huselid (1996) is used, which includes, the perceptual measures covering elements such as top management practices, employees' view of organization, product performance, and employee relation. The hypotheses here are: 
$H_{0}$ (3): The level of product performance for TQMf and TQMnf is the same.

$H_{0}(4)$ : The level of organizational performance for TQMf and TQMnf is the same.

Thefindings would warrant the worthiness of implementation of TQM in improving competitiveness of organizations. This paper hopes to establish a simple yet practical TQM quality implementation model to guide managers in developing nations when implementing TQM.

\section{METHODOLOGY}

The data collection was performed through questionnaire survey. The questionnaires were mailed to 3291 companies randomly selected from companies listed on the Kuala Lumpur Stock Exchange, FMM directory (1999), and - SIRIM list of ISO 9000 certified companies. It must be noted that the list of respondents was sorted to avoid double entry. A total of 405 sets of usable questionnaires were returned in
2000 yielding a response rate of 12.3 percent. From the responses, 123 responses claimed that they had implemented TQM.

In the "Background Information" section of the questionnaire, these questions were asked: (1) size of paid-up capital of the company, (2) years of operation, sectors, (3) product performance, and (4) organizational performance. The first three questions (1) - (3) were open-ended questions. Appendix 1 and 2 show the survey results in terms of paid-up capital, operating years, and sectors. The classification of sectors was done based on the Standard Industrial Trade Classification. For question (4), respondents were asked to indicate the level of product performance with respect to eight product dimensions relative to their competitors. These eight dimensions are features, performances, conformity, durability, reliability, repairable, style, and design. A five point Likert-scale was operationalized on these dimensions (with: $5=$ better than, $4=$ slightly better than, $3=$ similar to, $2=$ slightly worst than, 1=worst than).

\section{Appendix 1}

Companies by Range of Paid-Up Capital and Years of Operation

\begin{tabular}{|c|c|c|c|c|c|c|c|c|c|}
\hline & \multicolumn{4}{|c|}{ Paid-Up Capital (in RM) } & & \multicolumn{4}{|c|}{ Years of Operation } \\
\hline & \multicolumn{2}{|c|}{ Non-TQM } & \multicolumn{2}{|c|}{ TQM } & & \multicolumn{2}{|c|}{ Non-TQM } & \multicolumn{2}{|c|}{ TQM } \\
\hline & $\mathbf{N}$ & $\%$ & $\mathbf{N}$ & $\%$ & & $\mathbf{N}$ & $\%$ & $\mathbf{N}$ & $\%$ \\
\hline not specified & 66 & 23.40 & 42 & 34.15 & not & 8 & 2.84 & 6 & 4.88 \\
\hline below $0.5 \mathrm{mil}$ & 14 & 4.96 & 2 & 1.63 & below 5 years & 18 & 6.38 & 6 & 4.88 \\
\hline $0.5<=c<2.5 \mathrm{mil}$ & 57 & 20.21 & 17 & 13.82 & $5<=y<10$ years & 66 & 23.40 & 38 & 30.89 \\
\hline $2.5<=c<5 \mathrm{mil}$ & 18 & 6.38 & 12 & 9.76 & $10<=y<15$ years & 60 & 21.28 & 27 & 21.95 \\
\hline $5<=c<7.5 \mathrm{mil}$ & 27 & 9.57 & 4 & 3.25 & $15<=y<20$ years & 42 & 14.89 & 14 & 11.38 \\
\hline $7.5<=c<10 \mathrm{mil}$ & 5 & 1.77 & 1 & 0.81 & $20<=y<30$ years & 64 & 22.70 & 20 & 16.26 \\
\hline $10<=c<25 \mathrm{mil}$ & 41 & 14.54 & 15 & 12.20 & $>=30$ years & 24 & 8.51 & 12 & 9.76 \\
\hline $25<=c<50 \mathrm{mil}$ & 30 & 10.64 & 13 & 10.57 & & & & & \\
\hline $50<=c<100 \mathrm{mil}$ & 16 & 5.67 & 6 & 4.88 & & & & & \\
\hline$>=100 \mathrm{mil}$ & 8 & 2.84 & 11 & 8.84 & & & & & \\
\hline Total & 282 & 100.00 & 123 & 100.00 & Total & 282 & 00.00 & 123 & 100.00 \\
\hline
\end{tabular}


Appendix 2

Companies by Sectors

\begin{tabular}{|c|c|c|c|c|c|}
\hline & $\begin{array}{l}\text { Non- } \\
\text { TQM }\end{array}$ & TQM & & $\begin{array}{l}\text { Non- } \\
\text { TQM }\end{array}$ & TQM \\
\hline Agricultural \& Machinery Products & 5 & 1 & Iron \& Steel Products & 15 & 10 \\
\hline Automotive \& Component Products & 0 & 5 & Petroleum \& Gas & 0 & 3 \\
\hline Building Materials \& Related & & & Pharmaceutical, Medical Equipment & & \\
\hline Products & 18 & 12 & Cosmetics \& Toiletries & 2 & 2 \\
\hline $\begin{array}{l}\text { Cement \& Concrete Products } \\
\text { Ceramics \& Related }\end{array}$ & 12 & 2 & Plastic Resins \& Plastic Products & 13 & 6 \\
\hline Products & 4 & 1 & $\begin{array}{l}\text { Paper, Printing, Packaging } \\
\text { \& Labeling }\end{array}$ & 21 & 7 \\
\hline Chemical \& Adhesive Products & 13 & 12 & Rubber Products & 13 & 4 \\
\hline Diversified Industries & 4 & 1 & Stationaries & 1 & 0 \\
\hline Electrical \& Electronic Products & 58 & 37 & Textiles \& Wearing Apparel & 5 & 1 \\
\hline Food \& Baverages & 27 & 6 & Consultancy Services \& & & \\
\hline Foodwear \& Leather & & & Industrial Estates & 3 & 1 \\
\hline Products & 2 & 1 & Computer \& Related Products & 2 & 2 \\
\hline Funiture \& Related Products & 11 & 1 & Transportation \& Freight Forwarding & 1 & 1 \\
\hline Giftware \& Jewelry & 3 & 1 & Mining and Quarrying & 1 & 0 \\
\hline Industrial \& Engineering Products & 22 & 4 & Not specified & 16 & 2 \\
\hline
\end{tabular}

The reliability of this product performance construct is tested using Cronbach Alpha (1951). An a value of 0.93 was obtained and for all items, their values of "a if item deleted" is greater or equal to 0.92 . Hence, all the items are considered reliable and correlate internally with each other. Table 2 documents the reliability analysis result, and the respective mean scores for TQMf and TQMnf. A comparison of mean scores reveals that TQMf have a higher score than TQMnf for all dimensions, which implies that TQMf products performed better than TQMnf products. The fifth question was addressed using 14 statements on organiza-tional performance, which are shown in Table 3.

Table 2

Product Performance of TQM and Non-TQM Companies

\begin{tabular}{lccccccc}
\hline & & \multicolumn{2}{c}{ TQM } & \multicolumn{2}{c}{ Non-TQM } & & \\
\cline { 2 - 5 } & Alpha & Mean & $\begin{array}{c}\text { Standard } \\
\text { Deviation }\end{array}$ & Mean & $\begin{array}{c}\text { Standard } \\
\text { Deviation }\end{array}$ & $\begin{array}{c}\text { Mann- } \\
\text { Whitney }\end{array}$ & p-value \\
\hline Features & 0.92 & 4.09 & 0.84 & 3.99 & 0.86 & 13332 & 0.32 \\
Performance & 0.92 & 4.26 & 0.81 & 4.10 & 0.83 & 13725 & 0.07 \\
Conformity & 0.92 & 4.17 & 0.84 & 4.10 & 0.83 & 14571 & 0.42 \\
Durability & 0.92 & 4.14 & 0.82 & 4.00 & 0.85 & 12948 & 0.16 \\
Reliability & 0.92 & 4.28 & 0.81 & 4.13 & 0.81 & 12866 & 0.08 \\
Repairable & 0.93 & 3.94 & 0.89 & 3.77 & 0.89 & 10153 & 0.12 \\
Style & 0.92 & 3.87 & 0.86 & 3.85 & 0.86 & 12644 & 0.87 \\
Design & 0.92 & 3.99 & 0.88 & 3.88 & 0.88 & 12271 & 0.30 \\
\hline
\end{tabular}

Alpha $=0.93$ 
Table 3

Organizational Performance of TQM and Non-TQM Companies

\begin{tabular}{|c|c|c|c|c|c|c|c|c|}
\hline & & & TQ & $\mathbf{M}$ & Non & -TQM & & \\
\hline & & Alpha & Mean & $\begin{array}{l}\text { Standard } \\
\text { Deviation }\end{array}$ & Mean & $\begin{array}{l}\text { Standard } \\
\text { Deviation }\end{array}$ & $\begin{array}{l}\text { Mann- p } \\
\text { Whitney } \\
\text { U }\end{array}$ & p-value \\
\hline $\begin{array}{l}\text { Op1 } \\
\text { Op2 }\end{array}$ & $\begin{array}{l}\text { Company has clear mission } \\
\text { Understands iob obiective an }\end{array}$ & 0.95 & 4.40 & 0.69 & 4.24 & 0.84 & 6195 & 0.23 \\
\hline Op3 & $\begin{array}{l}\text { responsibilities } \\
\text { Company provides quality }\end{array}$ & 0.95 & 4.38 & 0.72 & 4.09 & 0.70 & 5163 & 0.00 \\
\hline Op4 & & 0.94 & 4.51 & 0.64 & 4.10 & 0.74 & 4720 & 0.00 \\
\hline Op5 & $\begin{array}{l}\text { good products \& services } \\
\text { Management can attract }\end{array}$ & 0.94 & 4.38 & 0.72 & 3.94 & 0.76 & 4649 & 0.00 \\
\hline Op6 & $\begin{array}{l}\text { employees } \\
\text { Management can retain }\end{array}$ & 0.94 & 3.79 & 0.76 & 3.60 & 0.86 & 6005 & 0.10 \\
\hline Op7 & $\begin{array}{l}\text { employees } \\
\text { Realistic commitment to }\end{array}$ & 0.94 & 3.71 & 0.84 & 3.55 & 0.92 & 6128 & 0.25 \\
\hline Op8 & $\begin{array}{l}\text { customers } \\
\text { Colleagues helpful and friendly }\end{array}$ & $\begin{array}{l}0.94 \\
0.95\end{array}$ & $\begin{array}{l}4.31 \\
4.09\end{array}$ & $\begin{array}{l}0.65 \\
0.78\end{array}$ & $\begin{array}{l}4.01 \\
3.93\end{array}$ & $\begin{array}{l}0.78 \\
0.74\end{array}$ & $\begin{array}{r}5398 \\
5861\end{array}$ & $\begin{array}{l}0.00 \\
0.07\end{array}$ \\
\hline $\begin{array}{l}\text { Op9 } \\
\text { Op10 }\end{array}$ & $\begin{array}{l}\text { Company respects employees } \\
\text { Growth of sales increased }\end{array}$ & 0.94 & 3.95 & 0.74 & 3.78 & 0.81 & 6078 & 0.13 \\
\hline $\begin{array}{l}\text { Op11 } \\
\text { Op12 }\end{array}$ & $\begin{array}{l}\text { effectively } \\
\text { Profit increased effectively } \\
\text { Company markets products }\end{array}$ & $\begin{array}{l}0.95 \\
0.95\end{array}$ & $\begin{array}{l}3.86 \\
3.65\end{array}$ & $\begin{array}{l}0.88 \\
0.96\end{array}$ & $\begin{array}{l}3.58 \\
3.39\end{array}$ & $\begin{array}{l}0.85 \\
0.91\end{array}$ & $\begin{array}{l}5429 \\
5597\end{array}$ & $\begin{array}{l}0.01 \\
0.03\end{array}$ \\
\hline Op13 & $\begin{array}{l}\text { and services effectively } \\
\text { Employees respect top }\end{array}$ & 0.94 & 3.96 & 0.78 & 3.62 & 0.87 & 5308 & 0.00 \\
\hline Op14 & $\begin{array}{l}\text { management } \\
\text { Company is a good corporate }\end{array}$ & 0.94 & 4.14 & 0.70 & 3.85 & 0.81 & 5493 & 0.01 \\
\hline & citizen & 0.94 & 4.05 & 0.82 & 3.91 & 0.84 & 6083 & 0.18 \\
\hline $\begin{array}{l}\text { Op15 } \\
\text { Op16 }\end{array}$ & Proud to work in company & 0.94 & 4.24 & 0.78 & 4.02 & 0.84 & 5761 & 0.04 \\
\hline $\begin{array}{l}\text { Op16 } \\
\text { Op17 }\end{array}$ & Recommend others to company & 0.94 & 4.05 & 0.90 & 3.83 & 0.94 & 5910 & 0.08 \\
\hline $\begin{array}{l}\text { Op17 } \\
\text { Op18 }\end{array}$ & Work made real contribution & 0.95 & 4.27 & 0.60 & 4.09 & 0.69 & 5876 & 0.07 \\
\hline Op18 & Good division communication & 0.95 & 3.99 & 0.80 & 3.75 & 0.78 & 5611 & 0.02 \\
\hline
\end{tabular}

Again a five point Likert-scale was used, with $5=$ exactly the same and $1=$ not at all. Reliability analysis results has an a value of 0.95 , with all 14 statements having "aif item deleted" values of 0.94 or above. The mean scores for all these 14 statements in terms of TQMf and TQMnf are shown in Table 3. These results shared a similar pattern with Table 2; where mean scores for TQMf are higher than TQMnf. In other words, TQMf tend to produce better results in their products and organizational performance, as compared to TQMnf.
In the "Quality Effort: TQM" section, respondents were first asked to indicate whether or not their organization had implemented TQM. For those who had implemented the TQM, they were asked to indicate:

(1) The time they took to fully implement the TQM concept in their organization,

(2) The training conducted for implementation of TQM,

(3) The benefits of TQM, 
(4) The degree of importance of nine given factors that affect achievement of TQM.

The first three question in this section, were again in an open-ended form. For the fourth question, the nine factors given are: employee involvement, top management involvement, employee satisfaction, compensation, customer, design and customer, knowledge, employee selection and development, and inventory reduction. Respondents were urged to respond using a 9-point Likert scale, with point $9=$ very closely related to point $1=$ not related. Their responses have an a value of 0.79 , with "a if item deleted" values of 0.75 or above for all nine factors. The mean scores for these factors and reliability test result are documented in Table 4.

\section{SURVEY FINDINGS AND ANALYSIS}

In terms of years required to fully implement TQM into their organizations' operation and system, out of the 123 TQM companies, 67 responded to the question. For this question, the majority indicated that it took them about two and a half years to fully implement TQM, but for some it took up to 10 years (see Figure 1). In terms of training conducted to support TQM implementation, out of the 123 TQM companies, 87 responded to the question asking about the types of training being carried out. Their types of training ranged from 1 to 4 types of training; the total responses on training (for all 87 respondents) are 188. From the responses, four types of training were identified:
- Understanding of TQM concept, and essential quality elements (21.62\%),

- Training of statistical tools (5'S, SPC, TPM) and quality techniques (QCC) (20.94\%),

- Training related to operations such as management $(22.97 \%)$, and

- Training on team work such as decision making, problem solving, and team building (8.79\%).

The percentage above is calculated by using the following steps: adding all the kinds of training being carried out by the companies (thus one company can mention more than one type of training), followed by calculating the sum of each category of training, then using the grand total of the responses of training as 100 percent, the respective percentage of the identified four major categories can then being derived. Note that the percentages shown in Table 1 represent the benefits of TQM. Table 5 shows the reasons for not adopting TQM. Both these were derived using the procedures explained above.

In terms of benefits of TQM implementation, out of the 123 TQM companies, 115 responded to the questions regarding the kind of benefits derived from TQM implementation. One company mentioned a number of benefits it experienced, leading to a total of 184 responses to this TQMbenefits question. Three areas of improvement were identified, i.e., employee performance $(26.09 \%)$, organizational performance $(53.8 \%)$, and understanding customers $(11.96 \%)$. The details of these areas are shown in Table 1. Again, the procedures for calculating the percentage of these three categories of benefits are: counting all 
the kinds of benefits cited in the questionnaire, after that calculating the sum of each category of benefits (in here three categories of benefits have been identified), then using the grand total of responses of benefits (184 responses) as 100 percent, the respective percentage of the three categories of benefits can then be derived. Taken together, results in Table 1, 2 and 3 imply that the adoption of TQM will produce favorable outcomes in product performance, organizational performance, and customer management relationship.

\section{Figure 1}

Years Required for Full Implementation of TQM

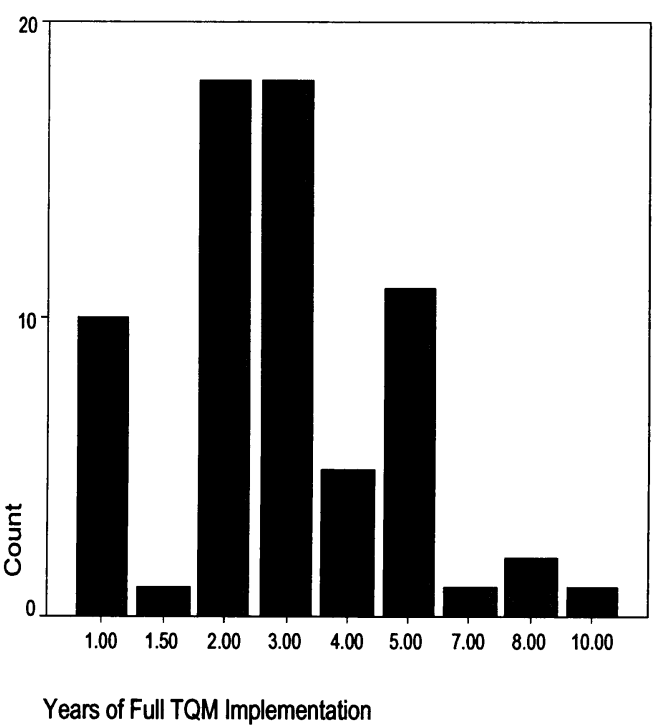

However, the mere comparison of mean score for product and organizational to judge the superiority of TQM companies over those non-TQM companies without going through statistical testing may lead to erroneous conclusions. Thus, the mean difference between TQMf and TQMnf with respect to product and organizational performance is statistically tested by employing the non-parametric test, Mann-Whitney U. The statistical value and its $p$-value for each product and organizational performance dimensions are shown in column "Mann-Whiteny $U$ " and column "pvalue" of Table 2 and 3 respectively. The $p$ value indicates the possibility of rejecting a true hypothesis at a $10 \%$ level of significance to determine the significance of examined items. With respect to product dimensions, only two could reject the null hypothesis where the mean difference for TQMf and TQMnf are the same; the two items are performance (with $p$-value of 0.07 ) and reliability (with $p$-value of 0.08 ) (see Table 2, the $p$-value column). On the other hand, only five items of the organizational performance constructs fail to reject the null hypothesis that the mean difference for TQMf and TQMnf are the same (see Table 3). These five items are clear company mission (Op1 with a $p$-value 0.23), management can attract people (Op5 with a $p$-value 0.10 ), management can retain people (Op6 with a $p$-value 0.25 ), company respects employees (Op9 with a $p$-value 0.13$)$, and company is a good corporate citizen (Op14 with a $p$-value 0.18 ). The overall results seem to suggest that implementation of TQM leads to favorable outcomes in organizational performance, but not entirely for product performance. In other words, hypothesis null $H_{0}(3)$ is only partially rejected, while null hypothesis $H_{0}(4)$ can be totally rejected.

The above findings have made the search for critical success factors of TQM implementation necessary. For this study, nine critical factors have been examined. From Table 4, the factors "employee involvement" and "top 
management involvement" scored high on the list, with mean scores of 8.64 and 8.50 respectively. The factors "knowledge" and "customer" are also perceived as important, with mean scores above 0.80 . To test whether the degree of importance of these factors varies between firms with different paid-up capital and years of operation, the Kruskal-Wallis test procedure was used. The chi-square test is not employed here as data fail to fulfill the requirement that the expected frequencies must be at least five for each paid-up capital range and years of operation range. The calcu- lated test value and its $p$-value, as shown in Table 4, ranging from a minimum of 0.11 to a maximum 0.98 , suggest that at a $10 \%$ level of significance, none of the factors could reject the null hypothesis. This implies that the degree of importance between TQMf with different paid-up capital range and operating years range is the same. In other words, irrespective of the firm's size and years of operation, the elements of "employee involvement" and "top management involvement" are too important to be ignored; this also means that hypotheses $H_{0}(1)$ and $H_{0}(2)$ cannot be rejected here.

\section{Table 4}

Critical Succes Factors of TQM Implementation

\begin{tabular}{|c|c|c|c|c|c|c|c|}
\hline & \multirow[b]{2}{*}{ Alpha } & \multirow[b]{2}{*}{ Mean } & \multirow[b]{2}{*}{ Standard } & \multicolumn{2}{|c|}{ Paid-up Capital } & \multicolumn{2}{|c|}{ Operating Years } \\
\hline & & & & $\begin{array}{l}\text { Kruskal- } \\
\text { Wallis }\end{array}$ & p-value & $\begin{array}{l}\text { Kruskal- } \\
\text { Wallis }\end{array}$ & p-value \\
\hline Employee involvement & 0.78 & 8.64 & 0.85 & 10.5 & 0.23 & 8.92 & 0.11 \\
\hline Top management involvement & 0.79 & 8.50 & 1.02 & 2.76 & 0.95 & 1.7 & 0.89 \\
\hline Employee satisfaction & 0.75 & 7.88 & 1.37 & 6.07 & 0.64 & 5.78 & 0.33 \\
\hline Compensation & 0.75 & 6.71 & 1.93 & 9.14 & 0.33 & 2.4 & 0.79 \\
\hline Customer & 0.78 & 8.03 & 1.78 & 7.48 & 0.49 & 1.41 & 0.92 \\
\hline Design and customer & 0.76 & 7.71 & 1.7 & 10.03 & 0.26 & 4.69 & 0.45 \\
\hline Knowledge & 0.78 & 8.25 & 0.97 & 6.17 & 0.63 & 4.24 & 0.52 \\
\hline $\begin{array}{l}\text { Employment selection and } \\
\text { development }\end{array}$ & 0.78 & 7.85 & 1.41 & 4.89 & 0.77 & 0.74 & 0.98 \\
\hline Inventory reduction & 0.78 & 6.87 & 2.04 & 7.7 & 0.46 & 3.29 & 0.66 \\
\hline
\end{tabular}

Although the above findings provide significant support for TQM implementation, there are still factors that hinder adoption and prevalence of TQM. Out of the 282 nonTQM firms, 215 companies responded to the question asking why their firm chooses not to implement TQM. A total of 216 responses have been obtained (as one company gives two reasons). The main reason for not implementing TQM is found to be associated with organizational constraints, which include items such as time, finance, resource, employ-ees, resistance of employees, top management support, and other priorities. Apart from these constraints, some respondents favored other quality approaches, although the percentage of it is relatively smaller than the "constraint" factors. Table 5, shows the responses to the reasons for not adopting TQM. Again, the procedures for calculating 
the percentage of these four major categories of barriers are: counting all the kind of reasons cited in the questionnaire, after that calculating the sum of each category of rea- sons, then using the grand total of responses of reasons ( 216 responses) as 100 percent, the respective percentage of the four categories of barriers can then be derived.

Table 5

Reasons for Not Employing TQM

\begin{tabular}{|c|c|c|c|}
\hline & & $\mathbf{N}$ & $(\%)$ \\
\hline \multirow[t]{10}{*}{ Constraints } & Financial & 9 & 3.95 \\
\hline & Time & 3 & 1.32 \\
\hline & Human resource & 8 & 3.51 \\
\hline & Resources & 7 & 3.07 \\
\hline & Company size/age & 10 & 4.39 \\
\hline & Lack of TQM understanding & 20 & 8.77 \\
\hline & Other priorities & 10 & 4.39 \\
\hline & In the process & 39 & 17.11 \\
\hline & Not ready yet & 32 & 14.04 \\
\hline & Not feasible & 3 & 1.32 \\
\hline \multirow[t]{2}{*}{ Employees attitudes } & Resistance from employees & 7 & 3.07 \\
\hline & Not instruction/interest of top management & 12 & 5.26 \\
\hline \multirow[t]{2}{*}{ Other approaches } & ISO & 23 & 10.09 \\
\hline & Others quality method & 20 & 8.77 \\
\hline \multirow[t]{4}{*}{ Criticism } & Too costly & 3 & 1.32 \\
\hline & Not applicable/suitable/practical & 10 & 4.39 \\
\hline & Not effective & 2 & 0.88 \\
\hline & Not necessary & 10 & 4.39 \\
\hline
\end{tabular}

\section{DICUSSIONS}

The period needed to fully implement the TQM reflects the required transformation time length of companies in developing countries from non-TQM to TQM oriented firm. Based on findings of Agus and Abdullah (2000), which suggested that longer adoption of TQM reaped greater financial performance, it is advisable for these TQM firms to continuously carry out the TQM exercise so that the initial preparation and investment does not go to waste. The long preparation period can also be interpreted as reflecting the generally fair level of understanding of TQM by Malaysian companies, which is shown in Table 5. This is shown in the results of training on TQM implementation, whereby understanding of TQM concepts and the essentials elements and the supporting management exercises were being 


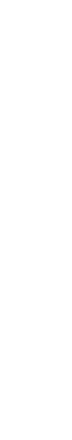

stressed in order to instill quality-oriented mindset in managers and employees. Furthermore, as the market in Malaysia is only partially open to foreign competition, the need of improving further and the drive for excellence are probably modest for some of the companies, making quality program implementation unnecessary or not critical. The situation becomes more complicated when employees start to resist the idea of the TQM due to unfamiliarity of TQM concept, and also the fear of managers of any potential threat towards their current position and authority. While the above statements may seem to contradict the phenomenon of adoption of other quality approaches such as ISO 9000, the explanation lies on the nature of these quality approaches. Specifically, adoption and implementation of ISO 9000 can actually be understood as an attempt of exploiting the business potential that can be offered by the ISO certification, rather than being motivated by the urge of excellence and improvement.

Notwithstanding the barriers and the general mindset of companies towards TQM implementation, this paper has suggested favorable outcomes of TQM in the context of developing nations. Specifically, the findings on benefits of TQM here mirrored those of developed nations (Chapman, et al., 1991; Peak, 1993; Gupta and Sagar, 1993). However, it may look strange why the product performance of TQMf cannot entirely outperform those of TQMnf. The plausible explanation maybe that many of the local firms and manufacturers are only involved in production and distribution of products while the design of the products and processes is done by their foreign counterpart. Local firms could even be just adopting it en- tirely from other manufacturers. As a result, the features and performance of the products depend greatly on external parties, rather than the firms themselves that implement TQM. The same can be said for non-TQM firms. Nevertheless, the practice of TQM principles such as employeeinvolvementand empowerment,customer focus and other management principles has enhanced the people management of TQMf as shown in Table 3.

\section{FOUR-STEP MODEL TO EFFECTIVE TQM IMPLEMENTATION}

Using the empirical results as the backbone and foundation, a four-step model of effective TQM implementation is proposed here. Specifically, when the top management of an organization intends to improve or solve their quality problem, they could adopt any quality approach or program. If they decide to choose TQM, certain measures need to be in place to ensure effective implementation of TQM. First of all, the top management needs to convince each and everyone in the organization (including managers, senior executive, workers) that the adoption of TQM is the best solution to an existing quality problem. During this period, open and effective communication should be present to convey the top management's commitment in executing TQM. When the employees are convinced, they will be less resistant to accept any changes. The seed of employee and top management commitment is also planted. The second step is to equip the employees with the relevant skills through appropriate TQM training. Training is important as it will make the transition period more 
successful, thus reducing the difficulty of TQM implementation. As the findings of this study suggest, the following elements should be included in the training: TQM concept, quality tools and techniques, operation and manage- rial skills, and elements of good team work. More emphasis should be placed on management skills since effectiveness of TQM depends on efficiency in management (Jaoko, 1994; Lee et al., 1999).

\section{Figure 2}

A Four-Step Model of Effective TQM Implementation

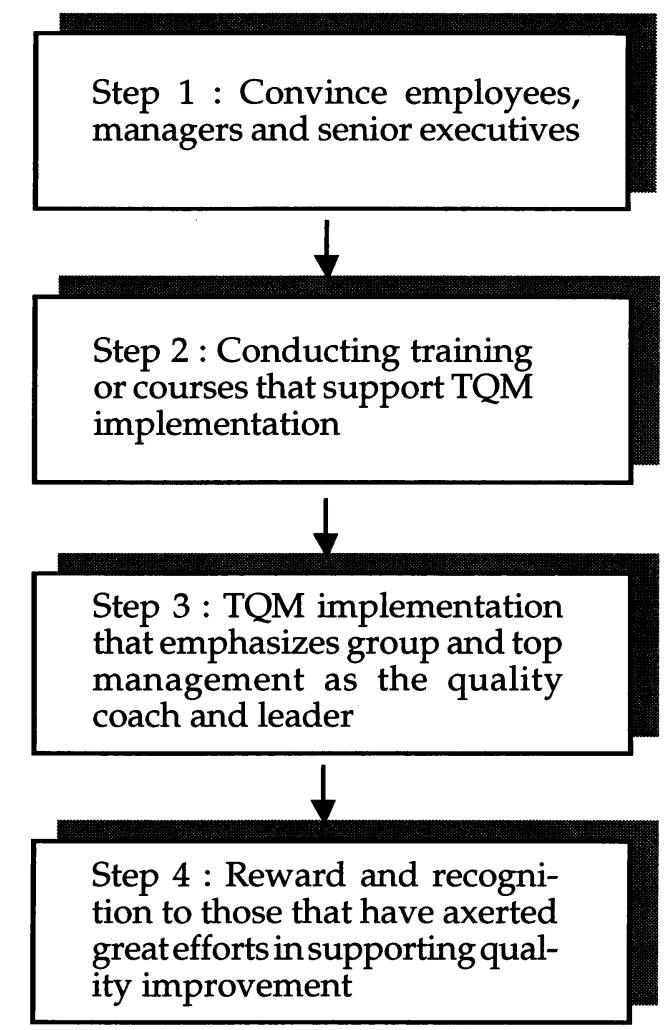

After the two preparation steps for TQM, the third step will be implementation of TQM. At this stage, top management should not consider that their role as the quality advocate has finished and completed. Instead, they should assume the role of quality leaders and facilitators who guide the whole organization in execution of TQM practices. In that way, top management is signaling to their employees that they are in full support of the TQM execution. During the execution of TQM, employees should be given the autonomy to carry out work. By allowing this, as claimed Thiagarajan and Zairi (1997), it will create a climate that fosters employee participation in continuous improvement. In addition, Thiagarajan and 
Zairi (1997) have advocated the formation of cross-functional teams or groups in implementation of projects or assignments, which help tear down territorialism. To complete the model, the fourth step is compensation and reward for TQM success, which acts as a stimulus and motivation for exerting extra effort to improve organizational performance. It has been found that the reward and recognition system is one of the tools that can improve employees and senior executive's involvement in TQM (Johnston and Daniel, 1991). However, the goals of this system should be attainable by the employees. Goals should be clear and developed in collaboration with the employees. The four-step model of effective TQM implementation is summarized in Figure 2.

\section{CONCLUSIONS}

This study has provided evidence that partially supports the claim that TQM implementation will improve organizational performance. Such evidence notwithstanding, it is still all too early to suggest that TQM is not as powerful and effective in improving company's performance. This paper holds that TQM has strong potential in stimulating the level of quality awareness and enhancing employee participation and commitment towards an organization's excellence. Therefore, this paper has proposed a four-step model that may support the successful implementation of TQM. For future study, it would be interesting to quantify the extent of inputs the TQM firms had during the execution of TQM practice, and then quantify the output or impact of TQM made on organizational performance.
Also, identification of resources used and the functions in supporting TQM is another area that is worth exploring.

\section{BIBLIOGRAPY}

Agus, A. (2001). A linear structural modelling of TotalQuality Management practices in manufacturing companies in Malaysia. Total Quality Management, 12(5): 561-573.

Agus, A. \& Abdullah, M. (2000). Total quality management practices in manufacturing companies in Malaysia : An exploratory analysis. Total Quality Management, 11(8): 1041-1051.

Ahire, S.J., Waller,M.A., \& Golhar, D.Y. (1996). Quality management in TQMversus nonTQM firms : An empirical investigation. International Journal of Quality $\mathcal{E}$ Reliability Management, 13(8): 8-27.

Aziz, Z.A. \& Chan F.L. (1998). Use of quality practices in Malaysia's Manufacturing. Total QualityManagement,9(4/5):S13-S16.

Besterfield, D.H., Besterfield, C.M., Besterfield, G.H.\&Besterfield, M.S. (1999). Total QualityManagement (2nd edition). New Jersey: Prentice Hall.

Chapman, R.L., Clarke, P. \& Sloan, T. (1991) TQM in continuous-process manufacturing : Dow-Corning (Australia) Pty Ltd. International Journal of Quality $\mathcal{E}$ Reliability Management, 8(5): 77-90. 
Cronbach, L. (1951). Coefficient alpha and the internal structure of tests. Psychometrika, 16(3): 297-333.

Crosby, P.B. (1979). Quality is Free. New York, NY: McGraw-Hill.

Delaney, J.T. \& Huselid, M.A. (1996). The impact of human resourcemanagement practices on perceptions of organizational performance. Academy of Management Journal, 39(4): 949-969.

(1) Deming, W.E. (1986). Out of the Crisis. Cam- bridge, MA: MIT Prees.

Eureka, W.E. \& Ryan, N. (1988). The Customer Driven Company : Managerial Perspectives on QFD. Dearbon, MI: ASI Press.

- FMM Directory (1999). 30th Edition. Published by Federation of Malaysian Manufactures.

Goh P.L. \& Ridway, K. (1994). The implementation of total quality management in small and medium-sized companies. The TQM Magazine, 16(2): 54-60.

Gupta, V.K. \& Sagar, R. (1993). Total quality control using PCs in an engineering company. International Journal of Production Research, 31(1): 161-172.

Hakes, C. (1991). Total Quality Management : A Key to Business Improvement. London: Chapman \& Hall.
Hamzah, A. \& Ho, S. (1994). TQM training for small and medium industries in Malaysia. Training for Quality, 2(2): 27-35.

Idris, M.A., McEwan, W. \& Belavendram, N. (1996). The adoption of ISO 9000 and Total Quality Management in Malaysia. The TQM Magazine, 8(5): 65-68.

Jaoko, B.B. (1994). Moving towards total quality management in Poland. Total Quality Management, 5(5): 283.

Johnston, C.G. \& Daniel, M.J. (1991), Customer Satisfaction through Quality : An international perspective. The Conference Board of Canada, Ottawa, Ontario.

Kanji,G.K., Tambi, A.M., \&Wallace,W. (1999). A comparative study of quality practices in higher education institution in the US and Malaysia. Total Quality Management, 10(3): 357-371.

Lau, H.C. \& Idris, M.A. (2001). The soft foundation of the critical success factors on TQM implementation in Malaysia. The TQM Magazine, 13(1): 51-60.

Lee S-F, Roberts, P., Lau W-S, Leung, R. (1999) Survey on Deming's TQM philosophies implementation in Hong Kong. Managerial Auditing Journal, 14(3): 136-145.

Mann, R.S. (1992). The development of a framework to assist in the implementation of total quality management, $\mathrm{PhD}$ thesis. Liverpool: University of Liverpool. 
Mohd. Yusof, S, \& Aspinwall, E. (1999). Critical success factors for total quality management implementation in small and medium enterprises. Total Quality Management, 10(4/5), S803-S809.

Oakland,J.S. (1993). Total Quality Management. Oxford: Butterworth-Heinemann.

Peak, M.H. (1993). Maquiladoras: where quality is a way of life. Management Review, 82(3),19-23.

Prabhu, V., Appleby A., Yarrow, D. \& Mitchell, E. (2000). The impact of ISO 9000 and TQM on best practice/performance. The TQM Magazine, 12(2): 84-91.

Puffer, S.M. \& McCarthy (1996). A framework for leadership in TQM context. Journal of Quality Management, 1(1): 109-130.

Saraph, J.V., Benson, P.G. \& Schroeder, R.G. (1989). An instrument for measuring the critical factors of quality management. Decision Sciences, 20(4): 810-829.

Saylor, J.H. (1992). TQM : Field Manual. New York, NY: McGraw-Hill.

Solis, L.E., Subba Rao, S., Raghu-Nathan, T.S., Chen C.Y \& Pan S-C. (1998). Quality management practices and quality results : A comparison of manufacturing and service sectors in Taiwan. Managing Service Quality, 8(1): 46-54.

Sun, H.Y. (1999). The patterns of implementing TQM versus ISO 9000 at the beginning of the 1990s. International Journal of Quality $\mathcal{E}$ Reliability Management, 16(3): 201-214.

Terziovski, M. \& Samson, D. (1999). The link between total quality management practice and organisational performance. Internatinal Journal of Quality \& Reliability Management, 16(3): 226-237.

Thiagarajan, T. \& Zairi, M. (1997a). A review of total quality management in practice : Understanding the fundamentals through examples of best practice applicationspart 1. The TQM Magazine, 9(4): 270-286.

Thiagarajan, T. \& Zairi, M. (1997b). A review of total quality management in practice : Understanding the fundamentals through examples of best practice applicationspart 2. The TQM Magazine, 9(5): 344-356.

Thiagarajan, T. \& Zairi, M. (1997c). A review of total quality management in practice : Understanding the fundamentals through examples of best practice applicationspart 3. The TQM Magazine, 9(6): 414-417.

Thiagarajan, T. \& Zairi, M. (1998). An empirical analysis of critical factors of TQM : A proposed tool for self-assessment and benchmarking purposes. Benchmarkingfor Quality Management \& Technology, 5(4): 291-303.

Thiagarajan, T.,Zairi,M.\&Dale, B.G.(2001). A proposed model of TQMimplementation based on an empirical study of Malaysian industry. International Journal of Quality $\mathcal{E}$ Reliability Management, 18(3): 289-306. 
Wilkinson, A. (1992). The other side of quality Zain, Z.M. \& Ahmad, Z.A. (2000). Total qual:Soft issues and the human resource dimension. Total Quality Management, 4(1): 323-329. ity management practice in Malaysia : How much is written. Malaysian Management Review, 35(1): 51-58. 